\title{
PEMETAAN POLA TANAM DAN KALENDER TANAM PADI SAWAH MENGGUNAKAN TEKNIK PENGINDRAAN JAUH
}

\author{
RIKA HERNAWATI ${ }^{1}$, AGUNG BUDI HARTO ${ }^{2}$, DEWI KANIA SARI ${ }^{1}$ \\ ${ }^{1}$ Jurusan Teknik Geodesi - FTSP, Institut Teknologi Nasional (Itenas) Bandung \\ ${ }^{2}$ Program Studi Geodesi \& Geomatika - FITB, Institut Teknologi Bandung (ITB) \\ Email: riecchah@gmail.com
}

\begin{abstract}
ABSTRAK
Pemantauan dan prakiraan hasil tanam padi sawah penting untuk dilakukan antara lain dalam rangka menjaga ketahanan pangan nasional. Saat ini, pemantauan pertumbuhan tanaman padi sawah dapat dilakukan dengan mengaplikasikan teknologi pengindraan jauh, antara lain dengan mendeteksi fenologi tanaman padi sawah yang terekam pada setiap piksel citra yang selanjutnya dapat digunakan untuk pemetaan pola tanam dan kalender tanam padi sawah. Penelitian ini bertujuan untuk mengembangkan algoritma deteksi fenologi padi sawah dengan menggunakan indeks vegetasi Enhanced Vegetation Index (EVI) dan Land Surface Water Index (LSWI) berkala yang diturunkan dari data citra MODIS, dengan menerapkan proses penapisan Gaussian. Penerapan teknik penapisan Gaussian pada data indeks vegetasi tersebut diharapkan dapat meminimalisasi derau, sehingga akan meningkatkan ketelitian hasil pendeteksian fenologi tanaman padi sawah. Wilayah studi mencakup 3 Kabupaten di Provinsi Jawa Barat bagian utara, yaitu Kabupaten Subang, Kabupaten Karawang, dan Kabupaten Bekasi. Hasil penelitian menunjukkan bahwa penerapan penapisan Gaussian pada metode deteksi fenologi padi sawah berbasis indeks vegetasi EVI dan LSWI berkala telah dapat meningkatkan ketelitian hasil deteksi tanggal-tanggal fenologis padi sawah. Keakuratan hasil estimasi luas tanam dan luas panen padi sawah divalidasi menggunakan data statistik dari Dinas Pertanian Kabupaten.
\end{abstract}

Kata Kunci: deteksi fenologi, EVI, LSWI, penapisan Gaussian

\begin{abstract}
Monitoring and forecasting yields of paddy rice are important to do, in order to maintain national food security. The current paddy crop growth monitoring can be done by applying remote sensing technology by detecting paddy phenology to produce the date of planting and harvest dates, which were recorded at each pixel of the digital image of rice field and can then be used for cropping pattern and planting calendar mapping. This research aims to develop a detection algorithm phenology paddy using vegetation indices Enhanced Vegetation Index (EVI) and Land Surface Water Index (LSWI) periodic image data derived from MODIS, by applying a Gaussian filtering process. The application of Gaussian filtering techniques to the data of vegetation indeces, EVI and LSWI, are expected to minimize the noise, thereby increasing the precision of detection of paddy rice crop phenology. The study area covers three districts in the northern part of West Java Province, i.e. Subang, Karawang and Bekasi. The results showed that the application of Gaussian filtering on the detection method of paddy rice phenology based on multitemporal vegetation indices EVI and LSWI can improve the precision of the detection of paddy phenological dates. The accuracy of the estimation results of the planting and harvested area of paddy were validated using statistical data from the District Agricultural Office.
\end{abstract}

Keywords: phenology detection, EVI, LSWI, Gaussian filtering

Reka Geomatika - 91 


\section{PENDAHULUAN}

Tanaman padi merupakan tanaman yang sangat penting bagi kehidupan masyarakat Indonesia sebagai bahan makanan sehari-hari. Hal tersebut menjadikan tanaman padi sebagai tanaman pangan yang paling banyak diproduksi oleh petani di Indonesia (BLP, 2007). Kendala yang dihadapi pada saat ini adalah kesulitan dalam hal memantau perkembangan tanaman padi secara cepat, akurat, dan berkelanjutan. Oleh karena itu dibutuhkan suatu teknologi yang dapat memberikan informasi untuk keperluan pemantauan, seperti pemantauan pola tanam dan kalender tanam untuk padi sawah, serta memprediksi luas tanam dan luas panen pada padi sawah di suatu area yang cukup luas (Sari, 2010).

Saat ini, pemantauan dan pembuatan data pola tanam dan kalender tanam padi sawah dapat dilakukan dengan mengaplikasikan teknologi pengindraan jauh dengan cara mendeteksi fenologi (tahap-tahap pertumbuhan) tanaman padi sawah, untuk cakupan area yang luas, jangka waktu yang cepat, serta hasil yang akurat (Sari, 2010). Fenologi mempelajari penampakan aktivitas tumbuhan yang terjadi secara berkala pada waktu-waktu tertentu dalam satu tahun (Martinez \& Gilabert, 2009).

Teknologi pengindraan jauh yang sering dimanfaatkan dalam bidang pertanian, khususnya untuk pemantauan padi sawah pada area yang cukup luas di antaranya dengan menggunakan citra MODIS (Moderate Resolution Imaging Spectroradiometer). Data MODIS multitemporal dapat digunakan untuk mengembangkan indeks vegetasi seperti NDVI, EVI, dan LSWI yang sensitif terhadap biomassa (massa organisme hidup) vegetasi dan kandungan air dari vegetasi (Xiao dkk., 2002; 2005). Dari indeks-indeks vegetasi tersebut dapat digunakan untuk mendeteksi fenologi tanaman untuk padi sawah (Sakamoto dkk., 2005; Xiao dkk., 2005; Sari, 2010; Son dkk., 2014).

Metode deteksi fenologi padi sawah ini dapat menentukan tanggal tanam, tanggal heading, dan tanggal panen untuk padi sawah yang kompleks pada lahan sawah dan memiliki kalender tanam heterogen (Sari dkk., 2010). Proses deteksi fenologi pada citra MODIS multitemporal dilakukan pada masing-masing piksel yang diidentifikasi sebagai piksel sawah berdasarkan data batas area pesawahan yang diperoleh dari peta tutupan lahan. Keakuratan hasil deteksi ditentukan oleh kualitas dari data indeks vegetasi EVI dan LSWI (Sari dkk., 2010; Xiao dkk., 2005). Data MODIS multitemporal yang digunakan, yaitu tipe MOD09A1 yang merupakan produk level 3 yang telah memperoleh koreksi atmosferis, akan tetapi diduga masih ada derau (noise) pada data reflektansi permukaan yang digunakan untuk menghitung indeks vegetasi EVI dan LSWI (Sari, 2010). Derau yang terdapat pada data indeks vegetasi tersebut dapat diminimalisasi dengan menerapkan teknik penapisan (filtering), seperti penapisan Gaussian. Keakuratan hasil deteksi ditentukan oleh kualitas dari data EVI dan LSWI yang akan berpengaruh pada hasil dari deteksi fenologi (Sari dkk., 2010). Penapisan Gaussian memiliki algoritmanya yang sederhana dan dapat menghasilkan kualitas data EVI dan LSWI yang lebih baik dibandingkan dengan data EVI dan LSWI tanpa proses penapisan.

Tujuan penelitian ini adalah mengembangkan algoritma deteksi fenologi padi sawah yang digunakan oleh Sari (2010) dengan menggunakan indeks vegetasi EVI dan LSWI yang diturunkan dari data Citra MODIS multitemporal, dengan menerapkan proses penapisan Gaussian untuk meningkatkan ketelitian hasil dan keakuratan deteksi fenologi padi sawah. Hasil deteksi fenologi digunakan untuk memetakan pola tanam dan kalender tanam padi sawah serta mengestimasi luas tanam dan luas panen yang terletak di Provinsi Jawa Barat bagian utara, yang meliputi 3 kabupaten yaitu Kabupaten Bekasi, Kabupaten Karawang, dan Kabupaten Subang. Ketiga wilayah ini memiliki area pesawahan yang luas sehingga memiliki

Reka Geomatika - 92 
tingkat homogenitas tutupan sawah yang relatif tinggi pada citra MODIS multitemporal yang beresolusi spasial 500 meter. Wilayah ini merupakan area strategis sentra produksi padi nasional.

\section{METODOLOGI}

\subsection{Data}

Data yang digunakan untuk proses deteksi fenologi padi sawah dapat dilihat pada Tabel 1.

Tabel 1 Data yang Digunakan untuk Proses Deteksi Fenologi Padi Sawah

\begin{tabular}{|c|l|l|l|l|}
\hline No. & \multicolumn{1}{|c|}{ Jenis Data } & \multicolumn{1}{c|}{ Tanggal Data } & \multicolumn{1}{c|}{ Penggunaan Data } & Sumber Data \\
\hline 1. & $\begin{array}{l}\text { MODIS-MOD09A1 } \\
\text { (Reflektansi kanal 1- } \\
\begin{array}{l}7 \text { komposit 8 harian, } \\
\text { resolusi 500 m) }\end{array}\end{array}$ & $\begin{array}{l}\text { Satu set data lengkap } \\
\text { satu tahun(46 citra) } \\
\text { tanggal 001, 009, 017, } \\
\text { 025, 033 ..., 353, 361 } \\
\text { DOY tahun 2012 }\end{array}$ & $\begin{array}{l}\text { Penurunan indeks } \\
\text { vegetasi EVI dan LSWI } \\
\text { untuk deteksi fenologi } \\
\text { padi sawah. }\end{array}$ & LPDAAC NASA \\
\hline 2. & $\begin{array}{l}\text { Peta Guna Lahan } \\
1: 50.000\end{array}$ & Tahun 2010 & Deliniasi Batas Sawah & $\begin{array}{l}\text { Badan Informasi } \\
\text { Geospasial (BIG) }\end{array}$ \\
\hline
\end{tabular}

\subsection{Metode Penelitian}

Metode yang digunakan dalam penelitian ini dapat dilihat pada Gambar 1.

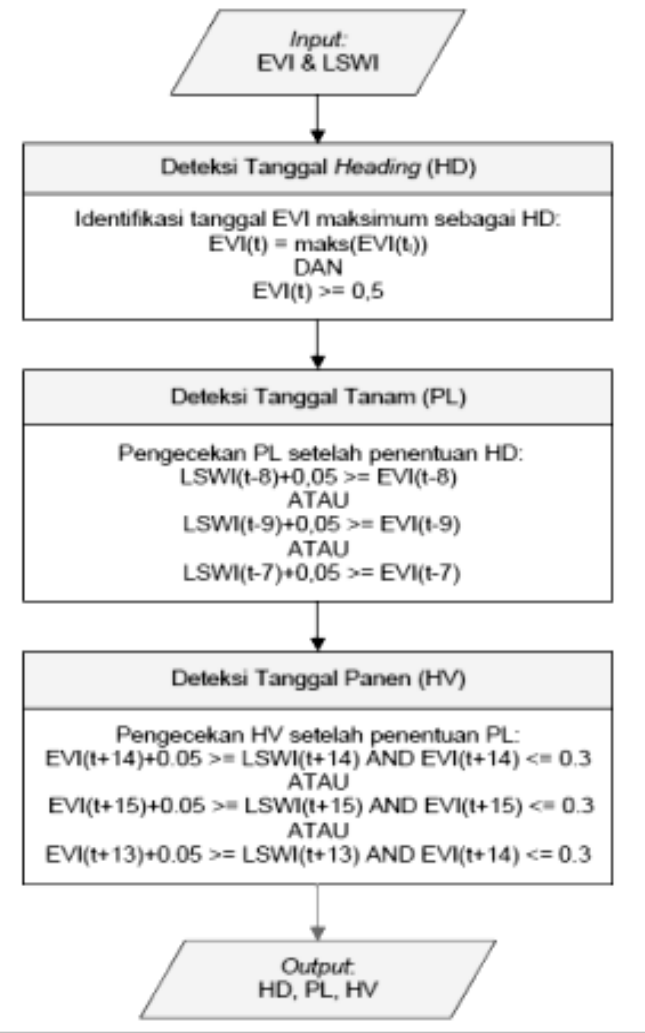

(a)

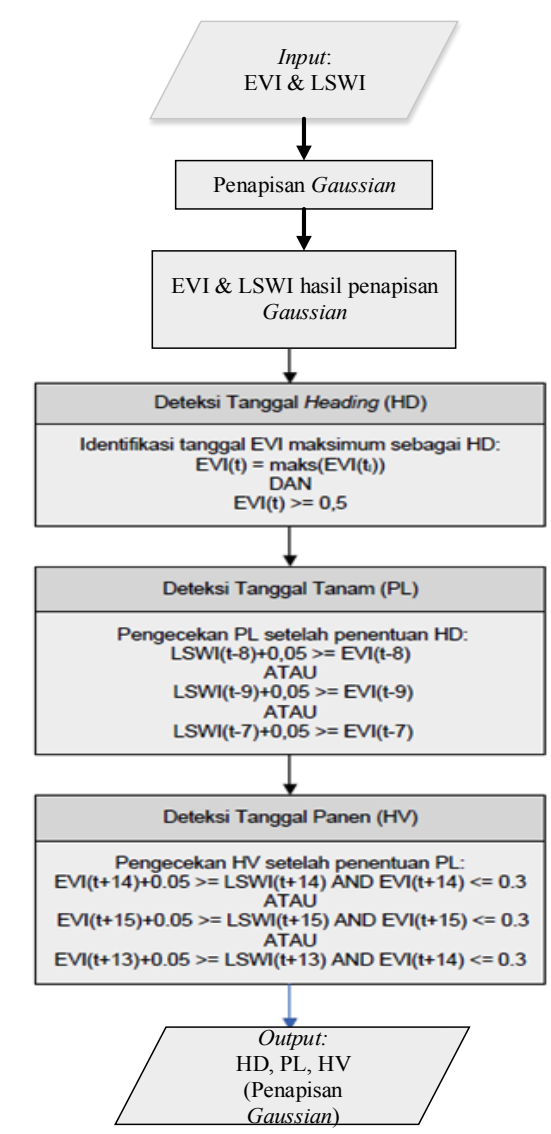

(b)

Gambar 1. Metodologi Penelitian 
Penelitian ini membandingkan hasil algoritma deteksi fenologi oleh Sari (2010) dengan algoritma deteksi fenologi melalui tahap penapisan Gaussian. Algoritma deteksi fenologi oleh Sari (2010) dapat dilihat pada Gambar 1 (a) sedangkan algoritma deteksi fenologi yang melalui tahap penapisan Gaussian dapat dilihat pada Gambar 1 (b).

Sari (2010) telah menjelaskan algoritma tahap-tahap deteksi fenologi padi sawah yang dimulai dari proses pengumpulan data Citra MODIS multitemporal. Untuk menghitung indeks EVI dan LSWI dari data Citra MODIS dalam mendeteksi fenologi padi sawah digunakan data reflektansi permukaan kanal merah (red), kanal NIR, kanal biru (blue), dan kanal SWIR1. Proses ini dimaksudkan untuk mentransformasi nilai digital piksel pada data MODIS multitemporal menjadi nilai reflektansi permukaan dengan cara nilai dikalikan dengan faktor skala reflektansi. Faktor skala reflektansi ini diperoleh dari data HDF (Hierarchical Data Format) Citra MODIS multitemporal yang mencantumkan informasi metadata mengenai citra tersebut. Dari hasil reflektansi tersebut, maka diperlukan algoritma untuk menghitung EVI dan LSWI, seperti yang dituliskan dalam persamaan (1) untuk indeks vegetasi EVI dan persamaan (2) untuk indeks vegetasi LSWI.

Algoritma yang digunakan untuk menghitung EVI dan LSWI adalah (Huete dkk., 2007):

$$
E V I=2,5 \times \frac{\rho_{N I R}-\rho_{\text {red }}}{\rho_{N I R}+6 \times \rho_{\text {red }}-7,5 \times \rho_{\text {blue }}+1}
$$

dimana:

$\rho_{\text {NIR }}=$ reflektansi inframerah-dekat

$\rho_{\text {red }}=$ reflektansi merah

$\rho_{\text {blue }}=$ reflektansi biru

$$
L S W I=\frac{\rho_{N I R}-\rho_{S W I R}}{\rho_{N I R}+\rho_{S W I R}}
$$

dimana:

$\rho_{\mathrm{NIR}}=$ reflektansi inframerah-dekat

$\rho_{\text {SWIR }}=$ reflektansi gelombang pendek inframerah

Algoritma dan threshold untuk mendeteksi tahap-tahap fenologi padi sawah yang dijabarkan oleh Sari (2010):

a. Tanggal Heading (HD)

Identifikasi tahap-tahap fenologi padi sawah diawali dengan mendeteksi untuk tanggal heading (HD). Pada data multitemporal hasil reflektansi padi sawah, nilai EVI maksimum terjadi di sekitar tanggal heading, 60 HST (Hari Setelah Tanam) (Domiri dkk., 2005). Pada metode deteksi fenologi ini tanggal ketika EVI mencapai nilai maksimum dalam grafik profil waktu didefinisikan sebagai estimasi tanggal heading dengan EVI $\geq 0,5$ sebagai threshold (Sari, 2010). Profil waktu EVI satu tahun dibagi menjadi 3 periode untuk mencari nilai maksimum EVI pada masing-masing caturwulan (4 bulan untuk setiap periode).

b. Tanggal Tanam (PL)

Pada periode ini, nilai EVI pada lahan padi sawah menurun kemudian naik kembali setelah padi ditanam, lalu kemudian nilai LSWI naik selama periode penggenangan(Xiao dkk., 2005). Karena tanggal heading dicapai sekitar 60 HST, maka setelah tanggal heading pada suatu piksel teridentifikasi selanjutnya dilakukan pendeteksian tanggal tanam dengan mengikuti threshold berikut ini (LSWI $+0,05) \geq$ EVI dalam delapan atau sembilan atau tujuh tanggal data komposit 8-harian (64 atau 72 atau 56 hari) sebelum tanggal heading. Sebagai contoh, jika tanggal heading 
adalah tanggal 265 DOY (Day Of Year) maka pengecekan nilai LSWI dan EVI tanggal tanam dilakukan pada tanggal 201 DOY atau 209 DOY atau 193 DOY.

c. Tanggal Panen (HV)

Setelah periode heading, nilai EVI dan LSWI pada lahan sawah mulai menurun karena dedaunan mengering dan mati, serta air dalam sawah dikeringkan sebelum dilakukan pemanenan. Nilai EVI kemudian menurun dengan cepat karena proses panen (Sakamoto dkk., 2005; Sari dkk., 2010) dan demikian pula dengan Nilai LSWI (Sari dkk., 2010). Nilai EVI pada tahap pemanenan berkisar 0,24 - 0,28 (Domiri dkk., 2005; Sari dkk., 2010). Dalam algoritma ini, masa tanam padi sawah diasumsikan berkisar 105 - 120 hari, berdasarkan pertimbangan bahwa mayoritas varietas padi sawah yang ditanam di wilayah studi adalah varietas IR64 dan Ciherang (Hermanto, 2006). Oleh karena itu, untuk mendeteksi tanggal panen (HV) digunakan threshold berikut ini EVI $\leq 0,3$ dan (EVI $+0,05) \geq$ LSWI dalam 14 atau 15 atau 13 kali tanggal data komposit 8-harian (112 atau 120 atau 104 hari) setelah tanggal penanaman. Sebagai contoh, jika tanggal tanam adalah tanggal 201 DOY maka pengecekan nilai EVI dan nilai LSWI tanggal panen dilakukan pada tanggal 313 DOY atau 321 DOY atau 305 DOY (Sari dkk., 2010).

Untuk algoritma metode deteksi fenologi padi sawah dengan penapisan Gaussian, data EVI dan LSWI dilakukan penapisan Gaussian terlebih dahulu untuk menghilangkan/mengurangi derau pada data tersebut. Berikut adalah persamaan yang digunakan dalam proses penapisan menggunakan Gaussian (Hsiaol dkk., 2007):

$$
\begin{aligned}
& G(x ; y)=\frac{1}{\sqrt{2 \pi \sigma}} e^{-\frac{x^{2}}{2 \sigma^{2}}} \\
& \text { dimana } \\
& \mathrm{x} \text { adalah jarak dari citra asli pada aksis horizontal } \\
& \text { y adalah jarak dari citra asli dalam aksis vertikal } \\
& \sigma \text { adalah simpangan baku dari distribusi Gaussian }
\end{aligned}
$$

\section{HASIL DAN PEMBAHASAN}

\subsection{Deteksi Fenologi Padi Sawah Tanpa Penapisan Gaussian}

Hasil dari deteksi fenologi ini memperlihatkan grafik profil waktu EVI dan LSWI dari data MODIS multitemporal komposit 8-harian pada tahun 2012 dengan cakupan wilayah studi tiga Kabupaten di wilayah Jawa Barat bagian utara, yaitu Kabupaten Bekasi, Kabupaten Karawang, dan Kabupaten Subang. Grafik profil waktu EVI dan LSWI tersebut menggambarkan variabilitas tahap-tahap fenologi padi sawah dan dapat mengidentifikasikan pola tanam dan panen padi sawah pada setiap pikselnya.

Identifikasi tahap-tahap fenologi padi sawah diawali dengan pendeteksian tanggal heading (HD), karena nilai EVI maksimum terjadi di sekitar tanggal heading 60 HST (Hari Setelah Tanam), sehingga pada metode ini tidak dapat mendeteksi padi yang ditanam pada Bulan November-Desember 2011, karena periode heading akan muncul 60 HST berikutnya, yaitu di Bulan Januari-Februari tahun 2012. Oleh karena itu dalam penelitian ini, untuk mendapatkan data pola tanam dan kalender tanam selain menggunakan data indeks vegetasi EVI juga menggunakan data indeks vegetasi LSWI yang dapat mengindikasikan terjadinya penggenangan penanaman padi yang ditandai dengan naiknya nilai LSWI yang melebihi nilai EVI, yaitu pada periode penanaman padi LSWI $\geq 0,2$; pada periode heading LSWI sekitar 0,3-0,4; dan periode panen LSWI < 0,2. Grafik profil waktu EVI dan LSWI dapat dilihat pada Gambar 2. 
Pada piksel padi sawah yang berlokasi di sekitar Kabupaten Bekasi terdapat dua kali musim panen yaitu pada musim tanam pertama padi ditanam sekitar Bulan Februari tanggal 60-68 DOY dan tanggal panen sekitar Bulan Juni pada tanggal 172-180 DOY, dan musim tanam kedua ditanam sekitar Bulan Juli pada tanggal 216-224 DOY dan dipanen sekitar Bulan November tanggal 330 DOY (Gambar 2).

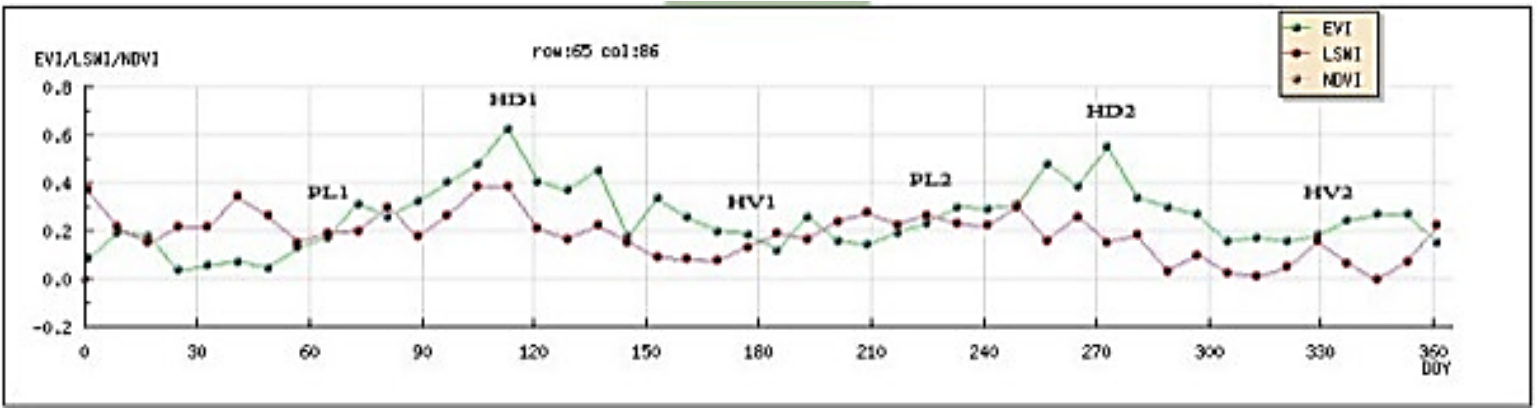

Gambar 2. Grafik Profil Waktu EVI dan LSWI pada Piksel Padi Sawah

\subsection{Deteksi Fenologi Padi Sawah Hasil Penapisan Gaussian}

Deteksi fenologi padi sawah dengan proses penapisan Gaussian pada umumnya memperlihatkan pemaparan yang serupa dengan deteksi fenologi padi sawah tanpa penapisan Gaussian, sedangkan yang berbeda adalah nilai dari hasil deteksi fenologi padi sawah tersebut. Grafik profil waktu EVI dan LSWI hasil penapisan Gaussian dapat dilihat pada Gambar 3.

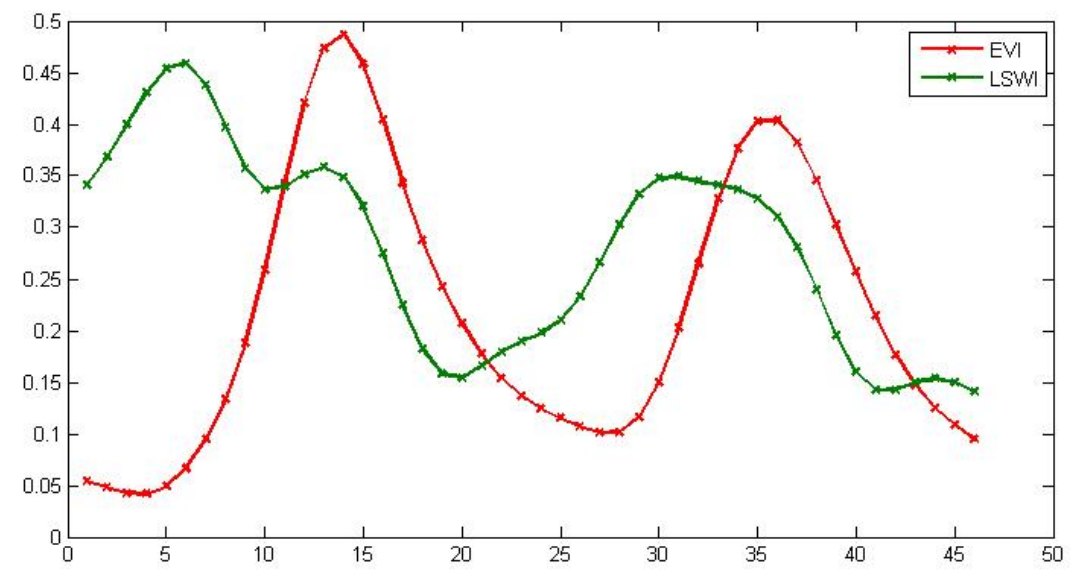

\section{Gambar 3. Grafik Profil Waktu EVI dan LSWI pada Piksel Padi Sawah}

Identifikasi tahap-tahap fenologi padi sawah hasil penapisan Gaussian diawali dengan pendeteksian tanggal heading (HD), karena nilai EVI maksimum terjadi di sekitar tanggal heading 60 HST (Hari Setelah Tanam), sehingga pada metode ini tidak dapat mendeteksi padi yang ditanam pada Bulan November-Desember 2011, karena periode heading akan muncul 60 HST berikutnya, yaitu di Bulan Januari-Februari tahun 2012. Oleh karena itu dalam penelitian ini, selain menggunakan data indeks vegetasi EVI juga menggunakan data indeks vegetasi LSWI yang dapat mengindikasikan terjadinya penggenangan penanaman padi yang ditandai dengan naiknya nilai LSWI melebihi nilai EVI, yaitu pada periode penanaman padi LSWI $\geq 0,2$; pada periode heading LSWI sekitar 0,3-0,4; dan periode panen LSWI $<0,2$. 


\subsection{Distribusi Spasial Tanggal Tanam Padi Sawah}

Pada Gambar 4 diperlihatkan distribusi spasial tanggal tanam hasil deteksi fenologi padi sawah pada setiap piksel yang diklasifikasikan 3 periode, dimana setiap periode diklasifikasikan ke dalam kelas bulanan yang terdiri dari 4 bulanan (periode).
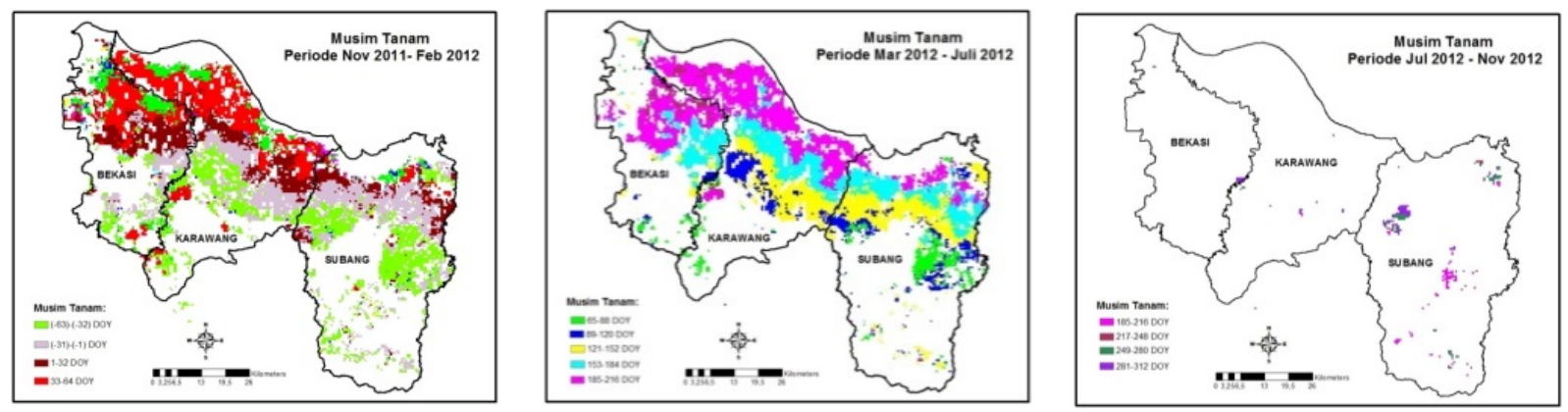

\section{Gambar 4. Distribusi Spasial Jadwal Tanam Padi Sawah di Kab. Bekasi, Kab. Karawang, dan Kab. Subang Provinsi Jawa Barat Tahun 2012}

Pada periode November 2011 - Februari 2012 penanaman padi musim hujan (MH) diawali dari bagian bawah pada daerah studi yang diklasifikasikan pada warna hijau muda untuk Bulan November 2011, kemudian bergerak ke arah utara yang diklasifikasikan pada warna abu-abu untuk Bulan Desember 2011, serta warna coklat untuk Bulan Januari 2012, dan warna merah untuk Bulan Februari 2012. Begitu juga halnya dengan penanaman padi MK I, diawali di bagian tengah yang diklasifikasikan dengan warna hijau tua untuk Bulan Maret, bergerak ke arah utara yang diklasifikasikan dengan warna biru tua untuk Bulan April, serta warna kuning untuk Bulan Mei, warna biru muda untuk Bulan Juni, dan ada sedikit penanaman warna merah muda untuk Bulan Juli. Adapun untuk penanaman padi MK II periode Juli-November 2012 hanya tampak di daerah Kabupaten Subang, yaitu warna merah muda untuk Bulan Juli, sedikit hijau tosca untuk Bulan September, sedikit sekali di Bulan Agustus warna, dan warna ungu untuk Bulan Oktober pada area Kabupaten Karawang serta Kabupaten Subang.

\subsection{Distribusi Spasial Tanggal Panen Padi Sawah}

Pada Gambar 5 diperlihatkan distribusi spasial tanggal panen hasil deteksi fenologi padi sawah pada setiap piksel yang diklasifikasikan ke dalam 3 periode, dimana setiap periode diklasifikasikan ke dalam kelas bulanan yang terdiri atas 4 bulanan (per periode).
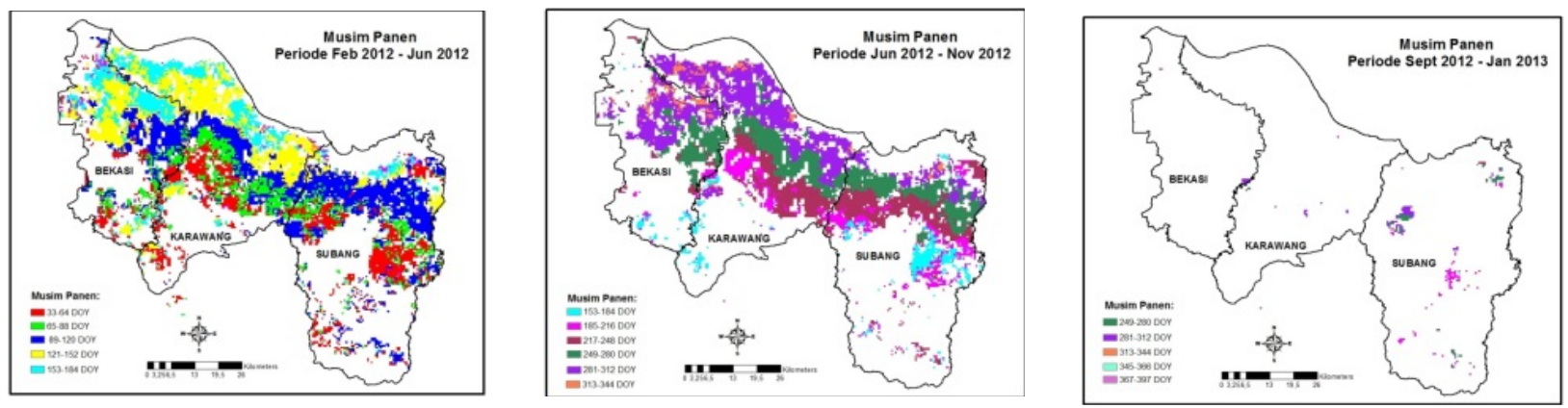

Gambar 5. Distribusi Spasial Jadwal Panen Padi Sawah di Kab. Bekasi, Kab. Karawang, dan Kab. Subang Jawa Barat tahun 2012 
Pada periode Februari-Juni 2012 jadwal panen padi untuk penanaman MH diawali dari bagian bawah pada daerah studi yang diklasifikasikan pada warna merah untuk Bulan Februari, kemudian bergerak ke arah utara yang diklasifikasikan pada warna hijau muda untuk Bulan Maret, warna biru tua untuk Bulan April, dan sedikit warna biru muda untuk panen di Bulan Juni. Pada periode Juni-November 2012 musim panen untuk penanaman MK I diawali di bulan Juni untuk warna biru muda lalu bergerak ke arah utara dan barat untuk panen di Bulan Juli warna merah muda dan Agustus warna ungu tua, panen pada Bulan September warna hijau tosca, warna ungu muda untuk Bulan Oktober, dan sedikit panen di Bulan November warna jingga. Untuk periode panen pada penanaman MK II terdapat di wilayah Subang dan Karawang pada Bulan September 2012, Oktober 2012, dan Januari 2013.

\subsection{Luas Tanam Padi Sawah Hasil Deteksi Fenologi}

Data MODIS yang digunakan dalam penelitian ini memiliki resolusi spasial $500 \mathrm{~m}$ x $500 \mathrm{~m}$ sehingga mencakup luas $250.000 \mathrm{~m}^{2}$ atau 25 hektar dengan asumsi semua piksel sawah pada data Citra MODIS dalam penelitian ini mempunyai cakupan $100 \%$ untuk padi sawah pada setiap pikselnya. Data luas tanam dan luas panen bulanan diperoleh dengan cara mengklasifikasikan tanggal panen dan tanam yang diperoleh dari hasil deteksi fenologi kedalam 11 kelas yang merepresentasikan 11 bulan dalam satu tahun, karena pada data MODIS multitemporal hasil deteksi fenologi untuk periode panen diawali pada Bulan Februari dan diakhiri pada Bulan Desember, sedangkan untuk periode tanam diawali pada Bulan November dan diakhiri pada Bulan September. Kemudian dihitung jumlah piksel yang terdapat pada setiap kelas sehingga diperoleh luas tanam dan panen untuk setiap bulannya selama satu tahun. Setelah itu dihitung luas tanam dan luas panen perperiode (4 bulanan) dan tahunan. Estimasi luas tanam padi sawah hasil deteksi fenologi dari 3 wilayah studi, yaitu Kab. Bekasi, Kab. Subang, dan Kab. Karawang dapat dilihat pada Tabel 2.

Tabel 2. Estimasi Luas Tanam Padi Sawah Hasil Deteksi Fenologi (dalam satuan Ha)

\begin{tabular}{|c|c|c|c|c|c|c|c|c|c|c|c|c|c|c|}
\hline \multicolumn{15}{|c|}{ Tanpa proses penapisan Gaussian } \\
\hline \multirow{2}{*}{ Kabupaten } & \multicolumn{4}{|c|}{ Caturwulan 1} & \multicolumn{4}{|c|}{ Caturwulan 2} & \multicolumn{3}{|c|}{ Caturwulan 3} & \multicolumn{3}{|c|}{ Jumlah Periode } \\
\hline & Nov & Des & Jan & Feb & Mar & Apr & Mei & Jun & Jul & Agst & Sept & 1 & 2 & 3 \\
\hline Bekasi & 6.214 & 9.672 & 17.142 & 17.706 & 9.361 & 2.079 & 2.574 & 12.508 & 19.197 & 3.218 & 25 & 50.736 & 26.495 & 22.440 \\
\hline Subang & 34.753 & 34.258 & 12.727 & 2.622 & 12.899 & 12.033 & 26.450 & 20.904 & 6.185 & 1.361 & 1.779 & 80.476 & 69.694 & 12.571 \\
\hline Karawang & 19.203 & 22.349 & 17.394 & 38.033 & 10.382 & 9.069 & 19.426 & 20.466 & 44.153 & 1.908 & 149 & 96.979 & 59.342 & 46.210 \\
\hline Total & & & & & & & & & & & & 228.191 & 155.531 & 81.221 \\
\hline \multicolumn{15}{|c|}{ Dengan proses penapisan Gaussian } \\
\hline \multirow{2}{*}{ Kabupaten } & \multicolumn{4}{|c|}{ Caturwulan 1} & \multicolumn{4}{|c|}{ Caturwulan 2} & \multicolumn{3}{|c|}{ Caturwulan 3} & \multicolumn{3}{|c|}{ Jumlah Periode } \\
\hline & Nov & Des & Jan & Feb & Mar & Apr & Mei & Jun & Jul & Agst & Sept & 1 & 2 & 3 \\
\hline Bekasi & 6.216 & 9.708 & 17.390 & 17.732 & 9733 & 2.030 & 2.547 & 12.583 & 18.429 & 3.218 & 25 & 51.046 & 26.893 & 21.672 \\
\hline Subang & 31.727 & 33.460 & 12.664 & 2.625 & 13.124 & 11515 & 25.536 & 19.519 & 10.225 & 715 & 1.632 & 80.476 & 69.694 & 12.572 \\
\hline Karawang & 16.649 & 16.745 & 18.628 & 34.166 & 20.862 & 8943 & 17.914 & 20.914 & 41.723 & 4.534 & 248 & 86.190 & 68.633 & 46.505 \\
\hline Total & & & & & & & & & & & & 217.712 & 165.220 & 80.749 \\
\hline
\end{tabular}

\subsection{Luas Panen Padi Sawah Hasil Deteksi Fenologi}

Perbandingan luas panen padi sawah hasil deteksi fenologi tanpa penapisan Gaussian dan dengan penapisan Gaussian dapat dilihat pada Tabel 3. 
Tabel 3. Estimasi Luas Panen Padi Sawah Hasil Deteksi Fenologi (dalam satuan Ha)

\begin{tabular}{|c|c|c|c|c|c|c|c|c|c|c|c|c|c|c|}
\hline \multicolumn{15}{|c|}{ Tanpa proses penapisan Gaussian } \\
\hline \multirow{2}{*}{ Kabupaten } & \multicolumn{4}{|c|}{ Caturwulan 1} & \multicolumn{4}{|c|}{ Caturwulan 2} & \multicolumn{3}{|c|}{ Caturwulan 3} & \multicolumn{3}{|c|}{ Jumlah Periode } \\
\hline & Feb & Mar & Apr & Mei & Jun & Jul & Agst & Sept & Okt & Nov & Des & 1 & 2 & 3 \\
\hline Bekasi & 6.263 & 8.322 & 12.606 & 19.864 & 9.089 & 1.683 & 2.201 & 13.846 & 17.463 & 2.626 & 25 & 47.055 & 26.819 & 20.114 \\
\hline Subang & 24.579 & 12.116 & 32.285 & 3.766 & 12.487 & 13.504 & 24.406 & 20.119 & 9.391 & 1.412 & 842 & 72.746 & 70.516 & 11.645 \\
\hline Karawang & 16.649 & 16.746 & 18.628 & 34.166 & 20.862 & 8.943 & 17.914 & 20.914 & 41.723 & 4.534 & 248 & 8.190 & 68.633 & 46.504 \\
\hline Total & & & & & & & & & & & & 205.991 & 165.968 & 78.264 \\
\hline \multicolumn{15}{|c|}{ Dengan proses penapisan Gaussian } \\
\hline \multirow{2}{*}{ Kabupaten } & \multicolumn{4}{|c|}{ Caturwulan 1} & \multicolumn{4}{|c|}{ Caturwulan 2} & \multicolumn{3}{|c|}{ Caturwulan 3} & \multicolumn{3}{|c|}{ Jumlah Periode } \\
\hline & Feb & Mar & Apr & Mei & Jun & Jul & Agst & Sept & Okt & Nov & Des & 1 & 2 & 3 \\
\hline Bekasi & 5.767 & 5.101 & 15.678 & 16.329 & 15.209 & 2.301 & 2.424 & 12.237 & 18.453 & 3.393 & 75 & 42.875 & 32.171 & 21.921 \\
\hline Subang & 24.702 & 13.229 & 32.120 & 3.775 & 5.684 & 10.785 & 13.770 & 11.755 & 2.017 & 1.287 & 965 & 73.826 & 4.199 & 7.269 \\
\hline Karawang & 19.822 & 15.139 & 14.866 & 30.303 & 21.210 & 8.945 & 19.302 & 20.541 & 41.651 & 4.287 & 24 & 80.130 & 69.996 & 45.962 \\
\hline Total & & & & & & & & & & & & 196.832 & 144.162 & 75.152 \\
\hline
\end{tabular}

\subsection{Hasil Estimasi Data MODIS Dengan Data Statistik Dinas Pertanian 3 Kabupaten}

Perbandingan luas tanam pada 3 kabupaten hasil estimasi MODIS dengan data statistik Dinas Pertanian dapat dilihat pada Tabel 4.

Tabel 4. Simpangan Rata-Rata (MD) dan Akar Rata-Rata Kuadrat Simpangan (RSMD) Luas Tanam Padi Hasil Estimasi MODIS dengan Data Statistik Dinas Pertanian di 3 Kabupaten (dalam satuan Ha)

\begin{tabular}{|c|c|c|c|c|c|c|c|c|}
\hline Periode & MD & $M D_{\text {(Gaussian) }}$ & RSMD & RSMD $_{\text {(Gaussian) }}$ & $\mathbf{n}$ & $\mathbf{r}$ & $\mathbf{r}_{\text {(Gaussian) }}$ & $\mathbf{r}^{2}$ \\
\hline \multicolumn{9}{|c|}{ Kab. Subang } \\
\hline bulanan & 654,1733 & 628,6538 & $1.203,839$ & $1.178,957$ & 220 & 0,543397 & 0,56232 & 0,2953 \\
\hline caturwulan & 1539,902 & 1446,16 & $2.424,884$ & $2.292,2$ & 60 & 0,71775 & 0,75144 & 0,5152 \\
\hline tahunan & $3.266,847$ & $3.842,497$ & $4.533,481$ & $5.464,988$ & 20 & 0,642848 & 0,7145 & 0,4133 \\
\hline \multicolumn{9}{|c|}{ Kab. Karawang } \\
\hline bulanan & 841,5297 & 869,1538 & $1.437,691$ & $1.444,72$ & 198 & 0,497338 & 0,479944 & 0,2473 \\
\hline caturwulan & $1.690,827$ & $1.697,786$ & $2.397,309$ & $2.314,016$ & 54 & 0,641705 & 0,634196 & 0,4118 \\
\hline tahunan & $3.960,163$ & $3.785,975$ & $5.134,917$ & $5.343,92$ & 18 & 0,413249 & 0,422412 & 0,1708 \\
\hline \multicolumn{9}{|l|}{ Kab. Bekasi } \\
\hline bulanan & 556,7468 & 553,2273 & 994,5091 & 992,6737 & 154 & 0,442093 & 0,445999 & 0,1954 \\
\hline caturwulan & $1.160,929$ & $1.145,31$ & $1.810,033$ & $1.816,351$ & 42 & 0,622529 & 0,626413 & 0,3875 \\
\hline tahunan & $2.703,643$ & $2.790,071$ & $3.921,358$ & $3.967,553$ & 14 & 0,749984 & 0,743316 & 0,5625 \\
\hline \multicolumn{9}{|c|}{ Total 3 Kabupaten } \\
\hline bulanan & 277 & 267,2 & 774,3 & 759,4 & 572 & 0,51 & 0,511 & 0,26 \\
\hline caturwulan & 1.490 & $1.452,26$ & 2.265 & $2.182,34$ & 156 & 0,66 & 0,67 & 0,44 \\
\hline tahunan & 3.355 & $3.539,586$ & 4.845 & $5.060,665$ & 52 & 0,62 & 0,65 & 0,39 \\
\hline
\end{tabular}


Total data luas tanam hasil estimasi MODIS tanpa melalui proses penapisan Gaussian dengan data luas tanam Dinas Pertanian di ketiga kabupaten pada data bulanan, data caturwulan, dan data tahunan menunjukkan tingkat korelasi yang moderat, yaitu $0,5<r<$ 0,7 dengan determinasi $r^{2}=0,26$ pada data bulanan; 0,44 pada data caturwulan; dan 0,39 pada data tahunan.

Pada data luas tanam hasil estimasi MODIS melalui proses penapisan Gaussian dengan data luas tanam Dinas Pertanian di ketiga kabupaten pada data bulanan, data caturwulan, dan data tahunan menunjukkan tingkat korelasi yang mendekati dengan tingkat korelasi pada data MODIS tanpa proses penapisan, yakni menunjukkan tingkat korelasi yang moderat, yaitu $0,5<r<0,7$ dengan determinasi $r^{2}=0,26$ pada data bulanan; 0,45 pada data caturwulan; dan 0,42 pada data tahunan.

Perbandingan luas panen pada 3 kabupaten hasil estimasi MODIS dengan data statistik Dinas Pertanian dapat dilihat Tabel 5.

Tabel 5. Simpangan Rata-Rata (MD) dan Akar Rata-Rata Kuadrat Simpangan (RSMD) Luas panen Padi Hasil Estimasi MODIS dengan Data Statistik Dinas Pertanian di 3 Kabupaten (dalam satuan Ha)

\begin{tabular}{|c|c|c|c|c|c|c|c|c|c|}
\hline Periode & MD & $M D_{\text {(Gaussian) }}$ & RSMD & $\operatorname{RSMD}_{\text {(Gaussian) }}$ & $\mathrm{n}$ & $r$ & $r_{\text {(Gaussian })}$ & $r^{2}$ & $\mathbf{r}^{2}$ (Gaussian) \\
\hline \multicolumn{10}{|c|}{ Kab. Subang } \\
\hline bulanan & 627,3665 & 522,56783 & 1215,48 & 983,95933 & 220 & 0,448523 & 0,507045 & 0,2012 & 0,2571 \\
\hline caturwulan & 1518,196 & 1156,609 & 2396,7149 & 1758,035 & 60 & 0,651154 & 0,718342 & 0,424 & 0,516 \\
\hline tahunan & 3686,291 & 2292,218 & 5297,2932 & 3287,98 & 20 & 0,602812 & 0,705399 & 0,3634 & 0,4976 \\
\hline \multicolumn{10}{|c|}{ Kab. Karawang } \\
\hline bulanan & 809,4088 & 799,6 & 1367,46 & 1324 & 198 & 0,511914 & 0,523 & 0,2621 & 0,2767 \\
\hline caturwulan & 1888,273 & 1793 & 2577,904 & 2343 & 54 & 0,560046 & 0,609 & 0,3137 & 0,371 \\
\hline tahunan & 4248,068 & 3989 & 5956,674 & 5134 & 18 & 0,511868 & 0,63 & 0,262 & 0,4 \\
\hline \multicolumn{10}{|c|}{ Kab. Bekasi } \\
\hline bulanan & 629,4464 & 596,0242727 & 1121,535 & 1025,746854 & 154 & 0,173043 & 0,3116 & 0,0299 & 0,097 \\
\hline caturwulan & 1353,629 & 1408,89067 & 1929,614 & 1991,31151 & 42 & 0,556412 & 0,42568461 & 0,3096 & 0,1812 \\
\hline tahunan & 3279,743 & 3474,95771 & 4656,564 & 4403,91205 & 14 & 0,74588 & 0,73564427 & 0,5563 & 0,5525 \\
\hline \multicolumn{10}{|c|}{ Total 3 Kabupaten } \\
\hline bulanan & 262,6 & 268,16 & 780,7 & 706,36 & 572 & 0,44 & 0,48 & 0,19 & 0,239 \\
\hline caturwulan & 1601 & 1444,896 & 2347 & 2039,019 & 156 & 0,6 & 0,618 & 0,36 & 0,382 \\
\hline tahunan & 3771,3 & 3198,331 & 5377 & 4301,948 & 52 & 0,601 & 0,655 & 0,36 & 0,429 \\
\hline
\end{tabular}

Total data luas panen hasil estimasi MODIS tanpa penapisan Gaussian dengan data luas panen Dinas Pertanian di ketiga kabupaten pada data bulanan menunjukkan tingkat korelasi yang lemah, yaitu $0,3<r<0,5$ dengan determinasi $r^{2}=0,19$; pada data caturwulan dan data tahunan menunjukkan tingkat korelasi yang moderat, yaitu $0,5<r<0,7$ dengan determinasi $r^{2}=0,36$ pada data caturwulan dan $r^{2}=0,361$ pada data tahunan. Data luas panen hasil estimasi MODIS melaui proses penapisan Gaussian dengan data luas panen Dinas Pertanian di ketiga kabupaten pada data bulanan menunjukkan tingkat korelasi yang lemah, yaitu $0,3<r<0,5$ dengan determinasi $r^{2}=0,239$; pada data caturwulan dan data tahunan menunjukkan tingkat korelasi yang moderat, yaitu $0,5<r<0,7$ dengan determinasi $r^{2}=0,38$ pada data caturwulan dan $r^{2}=0,4$ pada data tahunan. 


\section{KESIMPULAN}

Hasil deteksi fenologi tanaman padi yang berbasis data indeks vegetasi EVI dan LSWI yang diturunkan dari data MODIS multitemporal dengan menerapkan metode penapisan Gaussian dapat digunakan untuk menentukan tanggal heading, tanggal tanam, dan tanggal panen padi sawah berbasis piksel per piksel. Metode tersebut diimplementasikan di wilayah penelitian dengan menggunakan data MOD09A1 komposit 8 harian untuk tahun 2012 dengan resolusi $500 \mathrm{~m}$. Algoritma yang dikembangkan mampu mendeteksi tanggal tanam dan tanggal panen padi sawah. Hasil distribusi spasial tanggal tanam dan panen padi sawah dapat digunakan untuk menghitung luas tanam dan luas panen padi sawah pada tingkat kecamatan. Penjabaran dari ketiga kabupaten tersebut, menggambarkan bahwa masingmasing kabupaten pada data luas tanam dan luas panen dengan menggunakan proses penapisan Gaussian menunjukkan tingkat korelasi yang lebih baik dibandingkan dengan data tanpa proses penapisan Gaussian.

\section{DAFTAR PUSTAKA}

BLP (Badan Litbang Pertanian) (2007). Kalender Tanam Lahan Sawah. Sinar Tani, Edisi 7-13 Februari 2007.

Domiri, D.D., Adhyani, N.L., dan Nugraheni, S. (2005). Model Pertumbuhan Tanaman Padi Menggunakan Data MODIS untuk Pendugaan Umur Padi Sawah. Prosiding Pertemuan IImiah Tahunan MAPIN XIV, Surabaya, 14-15 September 2005.

Hermanto. (2006). Padi Ciherang Makin Populer. Warta Penelitian dan Pengembangan Pertanian, 25, No.2.

Hsiaol. P., Chou. S., dan Huang. F. (2007). Generic 2-D Gaussian Smoothing Filter for Noisy Image Processing. National University of Kaohsiung, Kaohsiung, Taiwan.

Huete, A., Didan, K., Leeuwen, W.V., Miura, T., Glenn, E. (2011). MODIS Vegetation Indices. Land Remote Sensing and Global Environmental Change. Springer. New York.

Martinez, B. \& Gilabert, M. A. (2009). Vegetation Dynamics from NDVI Time Series Analysis Using The Wavelet Transform. Remote Sensing of Environment 113 (2009) 1823-1842.

Sakamoto, T., Yokozawa, M., Toritani, H., Shibayama, M., Ishitsuka, N. \& Ohno, H. (2005). A Crop Phenology Detection Method Using Time-Series MODIS data. Remote Sensing of Environment, Vol. 96, pp. 366-374.

Sari, D.K. (2010). Estimasi Produktivitas Air Tanaman Padi Sawah di Wilayah Tropis Berbasis Kalender Tanam Heterogen Menggunakan Teknologi Peninderaan Jauh. Laporan Disertasi, Jurusan Teknik Geodesi \& Geomatika - Institut Teknologi Bandung.

Sari, D.K., Ismullah, I.H., Suladi, W.N., dan Harto, A.B. (2010). Detecting Rice Phenology in Paddy Fields with Complex Cropping Pattern Using Time Series MODIS Data A Case study of Northern Part of West Java - Indonesia. ITB Journal of Science, 42 A, No. 2, pp. 91-106.

Son, Nguyen-Thanh., Chen, Chi-Farn., Chen, Cheng-Ru., Duc, Huynh-Ngoc., Chang,Ly-Yu. (2014). A Phenology-Based Classification of Time-Series MODIS Data for Rice Crop Monitoring in Mekong Delta, Vietnam. Remote Sensing. 2014,6, 135-156; doi: $10.3390 /$ rs6010135.

Xiao, X., Boles, S., Frolking, S., Salas,W., Moore III, B., dan Li, C. (2002). Observation of Flooding and Rice Transplanting of Paddy Rice Fields at The Site to Landscape Scales in China using VEGETATION Sensor Data. International Journal of Remote Sensing, Vol. 23, pp. 3009-3022.

Xiao, X., Boles, S., Liu, J., Zhuang, D., Frolking, S., Li, C., Sales, W., dan Moore III, B. (2005). Mapping Paddy Rice Agriculture in Southern China Using Multi-Temporal MODIS Images. Remote Sensing of Environment, Vol. 95, pp. 480- 492. 